\title{
Bovine cysticercosis: a retrospective survey in the mountainous Region of Santa Catarina State, Brazil
}

\section{Cisticercose bovina: levantamento retrospectivo na Região Serrana de Santa Catarina, Brasil}

\author{
Mayckon Antonio Cardoso Padilha ${ }^{1 *}$; Gefferson Wasen²; Daniela Barp Coffy; \\ Antonio Pereira de Souza ${ }^{4}$; Anderson Barbosa de Moura ${ }^{5}$
}

\begin{abstract}
Bovine cysticercosis disease is prevalent worldwide, and is diagnosed frequently in slaughterhouses. This disease has an impact on animal production and public health due to Taenia saginata. In order to investigate the occurrence of bovine cysticercosis in the mountainous region of Santa Catarina state, Brazil, we performed a retrospective survey of beef carcasses that were positive for the parasite. We tabulated and analyzed the records of cattle that were slaughtered from 2003 to 2013, under the state inspection in Lages, Santa Catarina. These records were provided by Companhia Integrada de Desenvolvimento Agrícola de Santa Catarina (CIDASC). The data were analyzed using Chi-square test $(\mathrm{P} \leq 0.05)$ to correlate the cysticerci occurrence with the independent variables. The animals were from the 18 municipalities that represent Associação dos Municípios da Região Serrana (AMURES). Among the animals that were slaughtered during the study period, 7.06\% (1698/24055) were confirmed positive for cysticercosis during the visual inspection. Among the total cysts that were inspected, $25.79 \%$ and $74.20 \%$ were classified as viable and calcified, respectively. The most frequently parasitized organs were the head, with 876 cases (51.59\%) positive for cysticerci (321 [36.64\%] viable and 555 [63.36\%] nonviable) and the heart with 641 cases (37.75\%) positive for cysticerci (54 [8.42\%] viable and 587 [91.58\%] non-viable). In addition to the generalized infection (4.48\%), the tongue and the diaphragm were the next most commonly parasitized organs, with $3.71 \%$ and $2.47 \%$ cases positive for cysticerci, respectively. There was no correlation $(\mathrm{P}>0.05)$ between sex or age, and positive infection or cyst location. We identified statistical variations among the results for each of the evaluated years $(\mathrm{P}<$ 0.01). These reports indicated a significant increase in the infection rate over time, from $4.58 \%(2005)$ to $9.94 \%$ (2013). We analyzed the correlation $(\mathrm{P}<0.01)$ between the occurrence of cysticercosis and the origin of the animals as well as between the viability of cysts and their location in the body. These results suggest that the occurrence of bovine cysticercosis in the mountainous region of Santa Catarina is high and at an alarming rate. Bovine cysticercosis can lead to an economic loss and can endanger public health. Therefore, government agencies need to plan and implement measures in order to control this disease.
\end{abstract}

Key words: Beef cattle. Cysticercus bovis. Taenia saginata. Occurrence. Santa Catarina.

1 M.e, Médico Veterinário da Prefeitura Municipal de Lages, SC, Brasil. E-mail: mayck1000@hotmail.com

2 Médico Veterinário Autônomo, Lages, SC, Brasil. E-mail: geff_wasen@hotmail.com

3 Discente, Curso de Graduação em Medicina Veterinária do Centro de Ciências Agroveterinárias, Universidade do Estado de Santa Catarina, UDESC, Lages, SC, Brasil. E-mail: dbcoffy@gmail.com

4 Prof. Dr., Visitante Sênior, Instituto Federal Catarinense, Campus de Araquari, e Professor Voluntário do Programa de PósGraduação em Ciência Animal do Centro de Ciências Agroveterinárias, UDESC, Lages, SC, Brasil. E-mail: antonio.souza@ udesc.br

5 Prof. Dr., Programa de Pós-Graduação em Ciência Animal do Centro de Ciências Agroveterinárias, UDESC, Lages, SC, Brasil. E-mail: anderson.moura@udesc.br

* Author for correspondence

Received: July 17, 2017 - Approved: Feb. 18, 2018 


\section{Resumo}

A cisticercose bovina é uma doença de ampla distribuição geográfica, diagnosticada diariamente nos frigoríficos, e que causa impacto tanto na produção animal quanto na saúde pública, consequência do parasitismo por Taenia saginata. Com o objetivo de investigar a ocorrência da cisticercose bovina na região serrana do estado de Santa Catarina, Brasil, foi realizado um levantamento retrospectivo de ocorrência da cisticercose bovina, no período de 2003 a 2013, por meio da tabulação e análise dos registros da Companhia Integrada de Desenvolvimento Agrícola de Santa Catarina (CIDASC), de bovinos abatidos sob regime de inspeção estadual em Lages, SC. Os dados foram analisados através do Teste do Qui-Quadrado $(\mathrm{P} \leq 0,05)$, para correlacionar os resultados observados com as variáveis analisadas. Os animais foram provenientes dos 18 municípios que integram a Associação dos Municípios da Região Serrana (AMURES). Dos animais abatidos no período, 7,06\% (1.698/24.055) apresentaram cisticercos, na inspeção visual. Do total de cistos $25,79 \%$ e $74,20 \%$ foram classificados como viáveis ou calcificados, respectivamente. Os órgãos mais frequentemente parasitados foram cabeça, com 876 positivos $(51,59 \%)$ [dos quais 321 estavam viáveis $(36,64 \%)$ e 555 inviáveis $(63,36 \%)$ ], e coração com 641 notificações $(37,75 \%)$ [sendo 54 cisticercos viáveis $(8,42 \%)$ e 587 inviáveis $(91,58 \%)$ ], seguidos de localização generalizada, língua e diafragma com 4,48\%, 3,71\% e $2,47 \%$, respectivamente. Não foi observada correlação $(\mathrm{P}>0,05)$ entre sexo ou idade com a positividade e a localização dos cistos. Diferença estatística foi observada entre anos avaliados $(\mathrm{P}<0,01)$, tendo a ocorrência variado de $4,58 \%$ (2005) a 9,94\% (2013), indicando um aumento dos registros ao longo do tempo. Foi verificada correlação $(\mathrm{P}<0,01)$ entre a ocorrência de cisticercose e a procedência dos animais assim como entre a viabilidade dos cistos e sua localização. A ocorrência da cisticercose bovina na região serrana de Santa Catarina é alta e alarmante, que pode levar a perdas econômicas e colocar em risco a saúde da população, necessitando uma maior atenção do poder público e a tomada de medidas que visem seu controle.

Palavras-chave: Bovinos de corte. Cysticercus bovis. Taenia saginata. Ocorrência. Santa Catarina.

\section{Introduction}

Cysticercosis was reported for the first time in the $16^{\text {th }}$ century. However, its pathogenesis was not understood until the mid- $19^{\text {th }}$ century, when it was shown that tapeworm larvae (cysticerci) were responsible for cysticercosis in animals and humans (MEDEIROS et al., 2008). There are three species that affect humans: Taenia solium, T. saginata and T. asiatica that occur as the larval forms Cysticercus cellulosae, C. bovis and C. viscerotropic, respectively (EOM; RIM, 1993).

Bovine cysticercosis is a parasitic infection caused by the immature forms (metacestodes) of $T$. saginata. Humans are the only definitive hosts and harbor the adult form of the parasite (T. saginata), whereas the metacestode (C. bovis) has low host specificity (SOUZA et al., 2007a) and parasitize cattle, buffaloes, sheep, goats, reindeer, and giraffes.

Macroscopically, the viable cysts show a cystic appearance and a translucent wall, whereas the degenerated cysts show a calcareous cranial appearance with a diameter of approximately $0.5 \mathrm{~cm}$, a whitish to yellowish color, and firm consistency (ALMEIDA et al., 2006).

This is the most frequently diagnosed parasite in slaughterhouses and is the main cause of rejection because of the deterioration of carcass traits for human consumption (BAVIA et al., 2012; RONDINELLI et al., 2011). Infected carcasses and/ or organs with cysticercosis may be used for salting, canning, freezing or may be completely condemned depending on the severity of infection, which causes serious damage to the productive chain (PEREIRA et al., 2006).

The prevalence of cysticercosis in Brazil tends to be underestimated as it is based primarily on the records obtained from post-mortem inspection, which is a method considered to have low sensitivity especially for mild infections (BAVIA et al., 2012). Routine inspection detects only $27 \%$ of 
the infected animals (WALTHER; KOSKE, 1980). Despite various limitations, activities such as careful inspection of meat in slaughterhouses, judicious post-mortem sampling, and proper disposal of parasitized carcasses are important measures to prevent human infection. Additionally, these precautions will provide an early warning about the onset of infection in a community (CORREA et al., 1997; MORAIS et al., 2011; SOUZA et al., 2007b).

Cysticercosis is a human and animal health problem which has negative repercussions on meat production (REZENDE et al., 2006) and on raising of cattle in several states of Brazil. This issue poses limitations on the opportunities for meat export owing to reduced confidence of customers and reduced value of meat products. Therefore, cysticercosis requires a special attention from the inspection services of Brazil (RONDINELLI et al., 2011).

The present study provides updated information on this important zoonosis as so far very little has been known about the distribution and occurrence of bovine cysticercosis in the mountainous region of Santa Catarina state, Brazil.

\section{Materials and Methods}

We performed a retrospective survey of bovine cysticercosis records over a period of 11 years (2003 to 2013). We achieved this by tabulating and analyzing the data from the State Inspection Service of CIDASC on cattle slaughtered under state inspection in a slaughterhouse located in the municipality of Lages, in the mountainous region of Santa Catarina state, Brazil. The slaughtered animals were from 18 municipalities that form a part of AMURES (Associação dos Municípios da Região Serrana).

The 18 municipalities that constitute the AMURES occupy an area of approximately $16085 \mathrm{~km}^{2}$, corresponding to $16.87 \%$ of the territory of Santa Catarina state (AMURES, 2014). This area has 286291 inhabitants, corresponding to $4.63 \%$ of the population of Santa Catarina (IBGE, 2010).

The cattle herd in the municipalities of AMURES is stimated to be 631,400 animals that represent $14 \%$ of the total cattle in Santa Catarina state (IBGE, 2017). These animals are mostly distributed in small and medium family farms with an average of up to 20 animals (DAS, 2007), with the predominance of an extensive exploration system.

Among the total 24055 samples, 7211 (30\%) and $16844(70 \%)$ were from male and female cattle, respectively. The animals were grouped on the basis of age, according to the Guia de Trânsito Animal (GTA): below 24 months of age $(n=4659$, $19.4 \%)$ and above 24 months of age $(n=19396$, $80.6 \%$ ). Additionally, infected animals were categorized according to the location of cysts (head, heart, tongue, and diaphragm) and animals with cysts in or more different sites were classified into a generalized infection category.

We analyzed the data ( $\mathrm{R}$ DEVELOPMENT CORE TEAM, 2009) using Chi-Square Test (P $\leq 0.05$ ) in order to correlate the results with the independent variables (age, sex, origin, period, and location of the cysts).

The present study was approved by the Ethics Commission on the Use of Animals (CEUA) of the Universidade do Estado de Santa Catarina, under the protocol number 01.41.13.

\section{Results and Discussion}

In our study, the analysis of 24055 records of cattle that were slaughtered during the period from 2003 to 2013 led to the identification of 1698 infected animals, indicating an occurrence of $7.1 \%$ in the mountainous region of Santa Catarina state, Brazil (Table 1). This result was similar to the 7.14\% reported by Carvalho and Machado (2011) in Campina Verde, state of Minas Gerais. However, it was higher than the infection rates in other locations: $4.6 \%$ in the region of Muzambinho, Minas Gerais 
(RONDINELLI et al., 2011); 3.83\% (SOUZA et al., 2007b), 4.1\% (SOUZA et al., 2007a), and 5.50\% (OLIVEIRA et al., 2013) in Paraná; 0.7\% in Goiás (SILVEIRA NETO et al., 2011); and $1.95 \%$ in Rio de Janeiro (PEREIRA et al., 2006). Thus, bovine cysticercosis can be considered as an endemic parasitosis in the municipalities from AMURES, because the Pan American Health Organization and the World Health Organization consider the rates higher than $5 \%$ to be endemic for animal cysticercosis (OPAS, 1994).

In our analysis, we observed that animals of both the sexes and of variable ages had the same risk of infection (Table 1) as there were no statistically significant variations $(\mathrm{P}=0.3941$ and $\mathrm{P}=0.4984$, respectively).

Table 1. Total number $(\mathrm{N})$ of animals slaughtered and carrying cysticercosis in the municipality of Lages, Santa Catarina - Brazil, from 2003 to 3013; distributed by municipality, sex and age.

\begin{tabular}{|c|c|c|c|c|c|c|c|c|c|c|c|c|}
\hline & \multirow{2}{*}{ Categories } & \multicolumn{2}{|c|}{ Animals } & \multicolumn{4}{|l|}{ - } & \multicolumn{5}{|c|}{ Positive } \\
\hline & & $\mathbf{N}$ & $\%$ & $\mathbf{N}$ & $\% 1$ & $\%^{2}$ & cv & $\%^{1}$ & $\%^{2}$ & cc & $\%^{1}$ & $\%^{2}$ \\
\hline \multirow{18}{*}{ 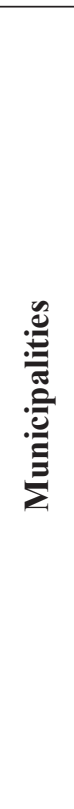 } & Lages & 12731 & 52.9 & 884 & 6.9 & 52 & 242 & 1.9 & 55 & 642 & 5.0 & 51 \\
\hline & São José do Cerrito & 1643 & 6.83 & 108 & 6.6 & 6.4 & 38 & 2.3 & 8.7 & 70 & 4.3 & 5.6 \\
\hline & Painel & 778 & 3.23 & 67 & 8.6 & 3.9 & 11 & 1.4 & 2.5 & 56 & 7.2 & 4.4 \\
\hline & Ponte Alta & 566 & 2.35 & 59 & 10 & 3.5 & 16 & 2.8 & 3.7 & 43 & 7.6 & 3.4 \\
\hline & Capão Alto & 3208 & 13.3 & 220 & 6.9 & 13 & 51 & 1.6 & 12 & 169 & 5.3 & 13 \\
\hline & Correia Pinto & 1704 & 7.08 & 138 & 8.1 & 8.1 & 33 & 1.9 & 7.5 & 105 & 6.2 & 8.3 \\
\hline & Bom Retiro & 34 & 0.14 & 4 & 12 & 0.2 & 0 & 0 & 0 & 4 & 12.0 & 0.3 \\
\hline & Cerro Negro & 330 & 1.37 & 17 & 5.2 & 1 & 3 & 0.9 & 0.7 & 14 & 4.2 & 1.1 \\
\hline & Palmeira & 248 & 1.03 & 21 & 8.5 & 1.2 & 4 & 1.6 & 0.9 & 17 & 6.9 & 1.3 \\
\hline & Anita Garibaldi & 167 & 0.69 & 15 & 9.0 & 0.9 & 2 & 1.2 & 0.5 & 13 & 7.8 & 1 \\
\hline & Urubici & 13 & 0.05 & 1 & 7.7 & 0.1 & 1 & 7.7 & 0.2 & 0 & 0 & 0 \\
\hline & Campo Belo do Sul & 1532 & 6.37 & 81 & 5.3 & 4.8 & 26 & 1.7 & 5.9 & 55 & 3.6 & 4.4 \\
\hline & Urupema & 82 & 0.34 & 11 & 13 & 0.6 & 0 & 0 & 0 & 11 & 13.0 & 0.9 \\
\hline & Bocaína do Sul & 238 & 0.99 & 11 & 4.6 & 0.6 & 2 & 0.8 & 0.5 & 9 & 3.8 & 0.7 \\
\hline & Bom Jardim Serra & 114 & 0.47 & 11 & 9.7 & 0.6 & 3 & 2.6 & 0.7 & 8 & 7.0 & 0.6 \\
\hline & Otacílio Costa & 351 & 1.46 & 31 & 8.8 & 1.8 & 4 & 1.1 & 0.9 & 27 & 7.7 & 2.1 \\
\hline & São Joaquim & 306 & 1.27 & 16 & 5.2 & 0.9 & 2 & 0.7 & 0.5 & 14 & 4.6 & 1.1 \\
\hline & Rio Rufino & 10 & 0.04 & 3 & 30.0 & 0.2 & 0 & 0 & 0 & 3 & 30.0 & 0.2 \\
\hline \multirow{2}{*}{ Sex } & Male & 7211 & 30 & 493 & 6.8 & 29 & 133 & 1.8 & 30 & 360 & 5.0 & 29 \\
\hline & Female & 16844 & 70 & 1205 & 7.2 & 71 & 305 & 1.8 & 70 & 900 & 5.3 & 71 \\
\hline \multirow{3}{*}{ Age } & $<24$ Months & 4659 & 19.4 & 340 & 7.3 & 20 & 86 & 1.9 & 20 & 254 & 5.5 & 20 \\
\hline & > 24 Months & 19396 & 80.6 & 1358 & 7.0 & 80 & 352 & 1.8 & 80 & 1006 & 5.2 & 80 \\
\hline & Total & 24055 & 100 & 1698 & - & 100 & 438 & 1.8 & 100 & 1260 & - & 100 \\
\hline
\end{tabular}

$\mathrm{cv}=$ viable cysticercosis; $\mathrm{cc}=$ calcified cysticercosis $; \mathrm{n}=$ number of animals

${ }^{1}$ Proportion between number of positive animals per variable and number of animals within each category.

${ }^{2}$ Proportion between number of positive animals of each variable and overall total of that variable.

We found a statistical correlation between the presence of $C$. bovis and the origin of inspected animals $(\mathrm{P}<0.01)$. In general, animals from municipalities with low municipal human development index (MHDI) averages, presented high prevalence of cysticercosis (Table 2). The low socio-economic and cultural levels of the population and the precariousness of sanitary conditions contribute to the contamination of pastures which is responsible for the occurrence of cysticercosis in 
cattle (BAVIA et al., 2012). Cysticercosis appears to be associated with small rural farmlands, where there may be close contact between humans and animals as well as a lack of basic sanitation and health education (SANTOS et al., 2010).

Table 2. Municipal Human Development Index (MHDI) versus average prevalence of cysticercosis in cattle slaughtered under state inspection in the municipality of Lages, SC, from 2003 to 2013.

\begin{tabular}{|c|c|c|c|c|c|}
\hline \multirow{2}{*}{ Municipalities } & \multicolumn{4}{|c|}{ MHDI $^{1}$} & \multirow{2}{*}{$\begin{array}{l}\text { Average prevalence o } \\
\text { cysticercosis }(\%)\end{array}$} \\
\hline & 1991 & 2000 & 2010 & Average & \\
\hline Lages & 0.551 & 0.674 & 0.77 & & \\
\hline São Joaquim & 0.491 & 0.589 & 0.687 & & \\
\hline Otacílio Costa & 0.51 & 0.635 & 0.74 & & \\
\hline Correia Pinto & 0.475 & 0.587 & 0.702 & & \\
\hline Urubici & 0.483 & 0.592 & 0.694 & 0.573 & 7.71 \\
\hline Bom Retiro & 0.45 & 0.56 & 0.699 & & \\
\hline São José do Cerrito & 0.355 & 0.502 & 0.636 & & \\
\hline Anita Garibaldi & 0.396 & 0.544 & 0.688 & & \\
\hline Campo Belo do Sul & 0.344 & 0.488 & 0.641 & & \\
\hline Ponte Alta & 0.418 & 0.52 & 0.673 & & \\
\hline Bom Jardim da Serra & 0.395 & 0.553 & 0.696 & & \\
\hline Bocaína do Sul & 0.388 & 0.505 & 0.647 & & \\
\hline Cerro Negro & 0.325 & 0.475 & 0.621 & & \\
\hline Capão Alto & 0.321 & 0.506 & 0.654 & 0.524 & 10.79 \\
\hline Palmeira & 0.361 & 0.544 & 0.671 & & \\
\hline Urupema & 0.462 & 0.578 & 0.699 & & \\
\hline Rio Rufino & 0.333 & 0.544 & 0.653 & & \\
\hline Painel & 0.425 & 0.528 & 0.664 & & \\
\hline
\end{tabular}

${ }^{1}$ Source: Brazilian Institute of Geography and Statistics (IBGE).

Among the 1698 infected animals, 438 (25.80\%) and $1260(74.20 \%)$ showed viable and calcified cysts, respectively. Statistical correlation was not observed between the viability of cysts and the age $(\mathrm{P}=0.8675)$ or the sex $(\mathrm{P}=0.5148)$ of the animals. The occurrence of viable and calcified cysts was observed in several animals and may be related to variable longevity of $C$. bovis in various tissues of the animal (PAWLOWSKI; SCHULTZ, 1972). Alternatively, the infections may have been acquired at different instances, or have had different rates of progression.

Regarding the location of the cysts, 876 (51.6\%) animals had parasites in the head, $641(37.8 \%)$ in the heart, $63(3.7 \%)$ in the tongue, $42(2.5 \%)$ in the diaphragm, and $76(4.5 \%)$ in two or more sites of the body (referred to as generalized infection). There were no statistical variations between the cyst location in the body and the sex $(\mathrm{P}=0.2828)$ or the age $(\mathrm{P}=0.223)$ of the cattle. However, there was a strong statistical correlation between the viability of cysts and the cyst location $(\mathrm{P}<0.01)$, with a high percentage of viable cysts in the head (73.3\%) and calcified cysts in the heart (46.6\%) (Table 3). Additionally, Rondinelli et al. (2011) observed a statistical variation $(\mathrm{P}<0.05)$ between the location 
of viable and calcified cysticerci, as viable cysts were more frequently found in the heart and head, followed by the tongue and diaphragm. We observed statistical variations $(\mathrm{P}<0.01)$ among the years that were analyzed, as the highest incidence of infection was recorded in the years 2012 and 2013 (Table 4). Several factors that may have contributed to this variation are: (i) animals with different rates of infection from multiple regions of origin, (ii) modifications in the post-mortem examination technique that was employed for the inspection, (iii) the number of cysticerci present in the carcass, and more specifically, (iv) the ability, criterion, and motivation of the inspectors (COSTA et al., 2012; SOUZA et al., 2007a).

Table 3. Distribution of cysts (total, viable and calcified) of Tania saginata, according to their anatomical location, in cattle slaughtered under state inspection in the municipality of Lages, SC, from 2003 to 2013.

\begin{tabular}{ccccccccc}
\hline \multirow{2}{*}{ Anatomic location } & \multicolumn{7}{c}{ Cysts (total, viable and inviable) } \\
\cline { 2 - 9 } & $\mathbf{N}$ & $\mathbf{\%}$ & $\mathbf{c v}(\mathbf{N})$ & $\mathbf{\%}^{\mathbf{1}}$ & $\mathbf{\%}^{\mathbf{2}}$ & $\mathbf{c c}(\mathbf{N})$ & $\mathbf{\%}^{\mathbf{1}}$ & $\mathbf{\%}^{\mathbf{3}}$ \\
\hline Head & 876 & 51.6 & 321 & 36.6 & 73.3 & 555 & 63.4 & 44 \\
Heart & 641 & 37.8 & 54 & 8.42 & 12.3 & 587 & 91.6 & 46.6 \\
Tongue & 63 & 3.71 & 13 & 20.6 & 2.97 & 50 & 79.4 & 3.97 \\
Diaphragm & 42 & 2.47 & 3 & 7.14 & 0.69 & 39 & 92.9 & 3.1 \\
Generalized & 76 & 4.48 & 47 & 61.8 & 10.7 & 29 & 38.2 & 2.3 \\
\hline Total & $\mathbf{1 6 9 8}$ & $\mathbf{1 0 0}$ & $\mathbf{4 3 8}$ & $\mathbf{2 5 . 8}$ & $\mathbf{1 0 0}$ & $\mathbf{1 2 6 0}$ & $\mathbf{7 4 . 2}$ & $\mathbf{1 0 0}$ \\
\hline
\end{tabular}

$\mathrm{cv}=$ viable cysticercosis; $\mathrm{cc}=$ calcified cysticercosis; $\mathrm{N}=$ number of animals.

${ }^{1}$ Relation between viable or calcified cysts and the total number of cysts in each location.

${ }^{2}$ Relation between viable cysts in a given location and the total of viable cysts.

${ }^{3}$ Relation between calcified cysts in a given location and the total of calcified cysts.

Table 4. Annual occurrence (\%) of cysticercosis in cattle slaughtered under state inspection in the municipality of Lages, SC, from 2003 to 2013.

\begin{tabular}{cccccccc}
\hline \multirow{2}{*}{ Year } & $\begin{array}{c}\text { Total slaughtered } \\
\text { animals }\end{array}$ & \multicolumn{7}{c}{ Positives } \\
\cline { 2 - 8 } & & $\mathbf{N}$ & $\mathbf{\%}$ & $\mathbf{c v}$ & $\mathbf{\%}$ & $\mathbf{c c}$ & $\mathbf{\%}$ \\
\hline 2003 & 817 & 58 & 7.1 & 16 & 27.6 & 42 & 72.4 \\
2004 & 1574 & 75 & 4.8 & 17 & 22.7 & 58 & 77.3 \\
2005 & 1265 & 58 & 4.6 & 14 & 24.1 & 44 & 75.9 \\
2006 & 2069 & 159 & 7.7 & 41 & 25.8 & 118 & 74.2 \\
2007 & 4304 & 320 & 7.4 & 70 & 21.9 & 250 & 78.1 \\
2008 & 3737 & 243 & 6.5 & 68 & 28 & 175 & 72 \\
2009 & 2223 & 164 & 7.4 & 37 & 22.6 & 127 & 77.4 \\
2010 & 2364 & 158 & 6.7 & 37 & 23.4 & 121 & 76.6 \\
2011 & 1964 & 111 & 5.7 & 33 & 29.7 & 78 & 70.3 \\
2012 & 1907 & 170 & 8.9 & 49 & 28.8 & 121 & 71.2 \\
2013 & 1831 & 182 & 9.9 & 56 & 30.8 & 126 & 69.2 \\
\hline Total & $\mathbf{2 4 0 5 5}$ & $\mathbf{1 6 9 8}$ & $\mathbf{7 . 1}$ & $\mathbf{4 3 8}$ & $\mathbf{2 5 . 8}$ & $\mathbf{1 2 6 0}$ & $\mathbf{7 4 . 2}$ \\
\hline
\end{tabular}

$\mathrm{cv}=$ viable cysticercosis $; \mathrm{cc}=$ calcified cysticercosis $; \mathrm{n}=$ number of animals. 
Bovine cysticercosis is responsible for a loss of approximately USD 164 million per year in Latin America (SCHANTZ et al., 1994) and an estimated loss of up to $30 \%$ in the price of slaughtered animals with viable cysts (GUIRRA, 2002). Thus, if we consider the 438 animals with viable cysts (Table 1), the mean fat ox weight of $67.5 \mathrm{~kg}$ (15 arrobas) (BEEFPOINT, 2009), and the carcass price of USD $2.64 \mathrm{~kg}^{-1}$ (BEEFPOINT, 2017; BCB, 2017), the economic depreciation can be estimated as USD 78051.60. These data demonstrate the economic importance of the necessity to control cysticercosis disease.

\section{Conclusion}

The occurrence of cysticercosis in the cattle present in the mountainous region of Santa Catarina Brazil was high (7.1\%) between the years 2003 and 2013, which resulted in economic loss and endangerment of public health. In conclusion, government agencies should exhibit more focused commitment in order to control this disease.

\section{Acknowledgements}

To the Fundação de Amparo à Pesquisa e Inovação do Estado de Santa Catarina (FAPESC) through Public Call no 06/2013-Apoio a Infraestrutura para Grupos de Pesquisa da UDESC (Grants: 3541/2013); Companhia Integrada de Desenvolvimento Agrícola de Santa Catarina (CIDASC), to the Fundo de Apoio à Manutenção e ao Desenvolvimento da Educação Superior no Estado de Santa Catarina (FUMDES) and Coordenação de Aperfeiçoamento de Pessoal de Nível Superior (CAPES).

\section{References}

ALMEIDA, D. O.; IGREJA, H. P.; ALVES, F. M. X.; SANTOS, I. F.; TORTELLY, R. Cisticercose bovina em matadouro-frigorífico sob inspeção sanitária no município de Teixeira de Freitas-BA: prevalência da enfermidade e análise anatomopatológica de diagnósticos sugestivos de cisticercose. Revista Brasileira de Ciência Veterinária, Niterói, v. 13, n. 3, p. 178-182, 2006.

ASSOCIAÇÃO DOS MUNICÍPIOS DA REGIÃO SERRANA. - AMURES. Institucional. Lages: AMURES, 2014. Disponível em: <http://amures.org.br/cms/pagina/ ver/codMapaItem/45162>. Acesso em: 08 set. 2016.

BANCO CENTRAL DO BRASIL - BCB. Taxas de câmbio. Brasília, DF: Banco Central do Brasil, 2017. Disponível em: <http://www4.bcb.gov.br/pec/taxas/ batch/taxas.asp?id=txdolar>. Acesso em: 25 jun. 2017.

BAVIA, M. E.; CARNEIRO, D. D. M. T.; CARDIM, L. L.; SILVA, M. M. N.; MARTINS, M. S. Estatística espacial de varredura na detecção de áreas de risco para a cisticercose bovina no estado da Bahia. Arquivo Brasileiro de Medicina Veterinária e Zootecnia, Belo Horizonte, v. 64, n. 5, p. 1200-1208, 2012.

BEEFPOINT. Agronegócio do boi: comercialização de animais para abate. São Paulo: BeefPoint, 2009. Disponível em: <http://www.beefpoint.com.br/cadeiaprodutiva/dicas-de sucesso/agronegocio-do-boicomercializacao-de-animais-para-abate-51249/>. Acesso em: 30 ago. 2016.

BEEFPOINT. Atacado de carne bovina: cotações. São Paulo: BeefPoint, 2017. Disponível em: <http:// www.beefpoint.com.br/cadeia-produtiva/cotacoes/ atacado-23-06-2017/>. Acesso em: 26 jun. 2017.

CARVALHO, L. S. S.; MACHADO, C. A. Ocorrência e localização de cisticercose em bovinos abatidos sob Inspeção municipal na cidade de campina verde, minas gerais - comunicação. Veterinária Notícias, Uberlândia, v. 17, n. 1, p. 50-53, 2011.

CORRÊA, G. L. B.; ADAMS, N. A.; ANGNES, F. A.; GRIGOLETTO, D. S. Prevalência de cisticercose em bovinos abatidos em Santo Antônio das Missões, RS, Brasil. Revista da FZVA, Uruguaiana, v. 4, n. 1, p. 77-80, 1997.

COSTA, R. F. R. D.; SANTOS, I. F. D.; SANTANA, A. P.; TORTELLY, R.; NASCIMENTO, E. R. D.; FUKUDA, R. T.; CARVALHO, E. C. Q.; MENEZES, R. C. Caracterização das lesões por Cysticercus bovis, na inspeção post mortem de bovinos, pelos exames macroscópico, histopatológico e pela reação em cadeia da polimerase (PCR). Pesquisa Veterinária Brasileira, Seropédica, v. 32, n. 6, p. 477-484, 2012.

DEPARTAMENTO DE SAÚDE ANIMAL - DAS. Estado de Santa Catarina: Proposta de zona livre de febre aftosa sem vacinação. Brasília, DF: Ministério da Agricultura, Pecuária e Abastecimento, 2007. 
EOM, K. S.; RIM, H. J. Morphologic descriptions of Taenia asiatica sp. n. The Korean Journal of Parasitology, Seoul, v. 31, n. 1, p. 1-6, 1993.

GUIRRA F. Cisticercose ainda provoca queda de 30\% no preço do boi. Goiânia: Revista Safra, 2002. Disponível em: <http://revistasafra.com.br/2002-03/cisticercose_ ainda provoca.htm $>$. Acesso em: 10 maio 2013.

INSTITUTO BRASILEIRO DE GEOGRAFIA E ESTATÍSTICA - IBGE. Censo Demográfico 2010. Brasília, DF: Instituto Brasileiro de Geografia e Estatística, 2010. Disponível em: <http://www.cidades.ibge. gov.br/ xtras/uf.php?lang $=\& \operatorname{coduf}=42 \&$ search $=$ santa-catarina $>$. Acesso em: 28 ago. 2016.

Pesquisa Pecuária Municipal 2017. Brasília, DF: Instituto Brasileiro de Geografia e Estatística, 2017. Disponível em: <https://sidra.ibge.gov.br/tabela/3939>. Acesso em: 29 nov. 2017.

MEDEIROS, F.; TOZZETTI, D.; GIMENES, R.; NEVES, M. F. Complexo Teníase-Cisticercose. Revista Científica Eletrônica de Medicina Veterinária, Garça, v. 6, n. 4, p. 675-684, 2008.

MORAIS, H. R.; PIRTOUSCHEG, A.; MOREIRA, M. D.; TAVARES, M. Inter-relação da viabilidade de Cysticercus bovis e órgãos-alvo de instalação em bovinos provenientes do Triângulo Mineiro. PUBVET, Londrina, v. 5, n. 7, p. 1034-1041, 2011.

OLIVEIRA, L. A.; OLIVEIRA, P. A.; RODRIGUES, G. V.; MERLINI, L. S.; GONÇALVES, D. D. Prevalência da cisticercose bovina em frigorífico sob inspeção federal na região noroeste do Paraná, Brasil. Enciclopédia Biosfera, Goiânia, v. 9, n. 17, p. 2064-2072, 2013.

ORGANIZACION PANAMERICANA DE LA SALUD - OPAS. Epidemiologia y control de la teniasis/ cisticercosis en America Latina. Washington DC: OPAS/ OMS, 1994. p. 297.

PAWLOWSKI, Z.; SCHULTZ, M. G. Taeniasis and cysticercosis (Taenia saginata). Advances in Parasitology, London, v. 10, n. 1, p. 269-343, 1972.

PEREIRA, M. A. V. C.; SCHWANZ, V. S.; BARBOSA, C. G. Prevalência da cisticercose em carcaças de bovinos abatidos em matadouros-frigoríficos do estado de Rio de Janeiro, submetidos ao Controle do Serviço de Inspeção Federal (SIF-RJ), no período de 1997 a 2003. Arquivos do Instituto Biológico, São Paulo, v. 73, n. 1, p. 83-87, 2006.

R DEVELOPMENT CORE TEAM, R. A language and environment for statistical computing. R Foundation for Statistical Computing, Vienna, Austria. 2009. Available at: <http://www.R-project.org $>$. Accessed at: 24 june 2016.
REZENDE, R. B. C.; FERNANDEZ, A. T.; COSTA, F.; SILVA, T. J. P. Ocorrência de cisticercose em bovinos abatidos clandestinamente no município de Silva Jardim, RJ. Revista Higiene Alimentar, São Paulo, v. 21, n. 140, p. 103-109, 2006.

RONDINELLI, S. M. B.; REZENDE, A. V.; SILVA, D. B.; SANTOS, R. S.; SIQUEIRA, L. J. R.; BOCOLI, L. E. B. Levantamento epidemiológico da ocorrência de casos de cisticercose bovina no município de Muzambinho MG. Veterinária Notícias, Uberlândia, v. 17. n. 2, p. 135$143,2011$.

SANTOS, D. V.; SANTO, M. C. B. E.; DOMINGUES, E. H.; KOHEK JÚNIOR, I.; FACIN, D. V.; VIDOR, A. C. Análise das principais lesões encontradas nos abatedouros registrados na CISPOA. Porto Alegre: Governo do Estado do Rio Grande do Sul, Secretária da Agricultura Pecuária e Agronegócio, 2010. v. 1 (Informativo técnico, 4). Disponível em: $<\mathrm{http}: / / \mathrm{www}$. agricultura.rs.gov.br/informativos-tecnicos-2016-11>. Acesso em: 10 ago. 2016.

SCHANTZ, P. M.; CRUZ, M.; SARTI, È.; PAWLOWSKI, Z. S. La erradicabilidad potencial de la teniasis y la cisticercosis. Boletín de la Oficina Sanitaria Panamericana, San Francisco, v. 5, n. 16, p. 465-458, 1994.

SILVEIRA NETO, O. J.; OLIVEIRA, R. D.; PEREIRA, F. D. O.; BASILE, A. D. C.; TAVEIRA, R. Z. Ocorrência e localização de cisticercos em bovinos abatidos e submetidos à Inspeção Federal no Estado de Goiás, Brasil. PUBVET, Londrina, v. 5, n. 21, p. 1130-1135, 2011.

SOUZA, V. D.; PESSÔA-SILVA, M. D. C.; KOWALCZUK, M.; MARTY, S.; THOMAZ-SOCCOL, V. Regiões anatômicas de maior ocorrência de Cysticercus bovis em bovinos submetidos à inspeção federal em matadouro-frigorífico no município de São José dos Pinhais, Paraná, de julho a dezembro de 2000. Revista Brasileira de Parasitologia Veterinária, Jaboticabal, v. 16, n. 2, p. 92-96, 2007a.

SOUZA, V. K.; PESSÔA-SILVA, M. C.; MINOZZO, J. C.; THOMAZ-SOCCOL, V. Prevalência da cisticercose bovina no estado do Paraná, sul do Brasil: avaliação de 26.465 bovinos inspecionados no SIF 1710. Semina: Ciências Agrárias, Londrina, v. 28, n. 4, p. 675-684, $2007 \mathrm{~b}$.

WALTHER, M.; KOSKE, J. K. Taenia saginata cysticercosis: a comparison of routine meat inspection and carcase dissection results in calves. The Veterinary Record, London, v. 106, n. 18-20, p. 401-402, 1980. 